\title{
O ENCONTRO DE TERRITORIALIDADES NA DIASPORA: JAPONESES E NORDESTINOS EM ASSAI-PR'.
}

\author{
Carla Holanda da Silva ${ }^{2}$
}

A presente proposta de pesquisa tem por intuito investigar o "encontro" de migrantes de dois contextos culturais no município de Assai - PR no Norte Velho do Paraná. Esta região recebeu, no início do século $X X$ grande número de imigrantes japoneses que se instalaram no seu espaço rural. Pouco tempo depois constatou-se a chegada de populações nordestinas que se inseriam no mesmo espaço. A convivência e a cooperação, principalmente no campo da agricultura, materializou-se através de trocas, mas também com demarcações culturais das duas etnias formando um conjunto num único espaço o que deixava surgir várias territorialidades e um conseqüente mosaico de territórios diferenciados. A pesquisa torna-se relevante, pois irá investigar a modificação das territorialidades existentes e o surgimento de possíveis novas territorialidades, em função da mescla identitária, baseado numa abordagem desconstrutivista que procura entender como a mútua inserção de etnicidades resulta numa situação de "disseminação" (H. BHABHA). Formando as novas territorialidades - complexas, conflituosas e/ou harmoniosas - os dois grupos participam na criação de espaços sociais relevantes na época moderna do capitalismo tardio e do culturalismo pósmoderno. Num primeiro momento, a pesquisa levantaria algumas abordagens de multiculturalismo e de hibdridismo cultural, para depois desenvolver conceitos geográficos de como se formam territórios sob estas condições, principalmente em base da nova abordagem de Rogério HAESBAERT. Posteriormente, os trabalhos de campo serão efetuados no município de Assai com entrevistas entre membros dos dois grupos, como preferência estes que já apresentam uma longa convivência com a outra etnia. Serão levantadas problemáticas econômicas, culturais e sociais. Numa terceira fase, a situação será analisada através de um cruzamento de perspectivas e na tentativa de uma abordagem do espaço híbrido na geografia cultural.

PALAVRAS-CHAVE: identidades territoriais; cultura diáspora; nipo-brasileiros, nordestinos.

\footnotetext{
${ }^{1}$ Orientador: Prof.Dr. Wolf-Dietrich Sahr

${ }^{2}$ Mestranda em Geografia (UFPR) - e-mail: carla_holanda@hotmail.com
} 